\title{
Heat research guides current practices in professional tennis
}

\author{
Todd S Ellenbecker, ${ }^{1}$ Kathleen A Stroia ${ }^{2}$
}

Professional tennis places extraordinary demands on elite tennis players. Previously published profiles characterise the inherent physiological demands of tennis play and the adaptations incurred by elite-level tennis players. These include the requirement of repeated maximal level exertions during points with average durations ranging between 2 and $>8$ s depending on the match surface and player's gender. ${ }^{1}{ }^{2}$ Match durations of greater than $5 \mathrm{~h}$ can be encountered. During these matches, a work rest ratio of $1: 2$ is reported with movement demands requiring a mean of three shots, 4.2 directional changes and an average distance of $3 \mathrm{~m}$ is required to optimally position the body for shot production and execution. All of this can occur during extreme environmental temperatures played in outdoor stadiums and tennis facilities.

Several previous studies have profiled the body core temperature responses during competition as well as estimated

\footnotetext{
${ }^{1}$ ATP World Tour, Physiotherapy Associates Scottsdale Sports Clinic, Scottsdale, Arizona, USA; ${ }^{2}$ WTA Women's Tennis Association, St Petersburg, Florida, USA

Correspondence to Todd S Ellenbecker, Senior Director Medical Services, ATP World Tour, Physiotherapy Associates Scottsdale Sports Clinic, Scottsdale, AZ 85258, USA;

tellenbecker@atpworldtour.com
}

sweat rates (1 to over $3.5 \mathrm{~L} / \mathrm{h}$ ) from elitelevel tennis players during matches in challenging thermal environmental conditions. ${ }^{3} 4$ Core body temperatures (CBTs) have been recorded and have peaked at $38.9-39.1^{\circ} \mathrm{C}$ in women and men professional players. ${ }^{5}{ }^{6}$ Even higher CBTs were recorded by Périard et $a l^{7}$ who studied elite male tennis players during tennis match play in cool $\left(\sim 19^{\circ} \mathrm{C}\right.$ wet bulb globe temperature (WBGT)) and hot conditions $\left(\sim 34^{\circ} \mathrm{C}\right.$ WBGT $)$. The mean CBTs were $\sim 38.7^{\circ} \mathrm{C}$ under cool and $\sim 39.4^{\circ} \mathrm{C}$ under hot conditions, respectively.

These high sweat rates and high CBTs do show that the body's cooling system has to work very hard to reduce excessive heat when the metabolic rate and environmental heat load are high.

The inherent demands imposed by the sport of tennis played at the highest level have led to procedural intervention by the medical teams caring for professional tennis players at events worldwide played in challenging environmental temperatures. Research works such as those presented in this special issue of the BJSM provide rationale and influence the development of these intervention strategies to optimise performance and prevent injury and illness from the environmental and physiological challenges of elite-level tennis play.
Currently, prevention strategies are employed on the Association of Tennis Professionals (ATP) and Women's Tennis Association (WTA) tours for its professional players that reflect evidence-based approaches to provide optimal care. These prevention strategies include player and coach education regarding proper nutrition and hydration for match preparation, match performance and post-match recovery. Knowledge of sweat rates and the body's cooling mechanisms allow clinicians to guide players through specific interventions to address these physiological responses with individualised sweat analysis and tailored personalised recommendations offered at ATP and WTA tournaments. Practices conducted in the training and locker rooms at ATP and WTA professional-level tournaments worldwide are employed to monitor fluid loss and recovery, such as weighing players, specific gravity urine strips and monitoring urine colour (see online supplementary figure S1) prior to and following practice sessions and matches. The provision and recommendation of water and electrolyte beverages to address fluid and electrolyte loss is an essential part of intervention strategies coupled with the careful monitoring of physiological parameters. The use of external body cooling procedures on court with the use of fans induced shade via umbrellas or court structures, and the application of ice towels ${ }^{8}$ is currently recommended to provide on-court relief during tournament play in stressful thermal conditions. In addition, scientific advancements in sporting apparel and materials have 
improved on-court cooling capabilities. Evidence-driven use of ice bath immersion to reduce core temperature postcompetition in extreme temperatures is also commonly seen. ${ }^{8-10}$

Application of heat illness-related research led to the development of the WTA's Extreme Weather Conditions Rule. This rule, being designed with the players' safety in mind, allows for a short break in play to permit safety interventions, such as cooling measures, prior to the final set in singles matches being played in extreme weather conditions. ${ }^{5}$

Clinicians are indebted to the researchers who study and author scientific investigations and literature reviews on these topics to enable the continued evolution of clinical practices to protect, prevent and treat elite tennis players performing in extended thermal environmental conditions. The importance of this research can be demonstrated in the player and coaching education pieces provided by the professional tours (see online supplementary figure S2). Dissemination of research provided by the scientific community is essential to provide the evidence needed to educate and modify players' behaviours to optimise performance and prevent illness and injury. Continued advancement of knowledge in this area will lead to adapted and nouveau procedures that

optimise current athletic care in the sport of tennis.

\section{Competing interests None.}

Provenance and peer review Not commissioned; externally peer reviewed.

- Additional material is published online only. To view please visit the journal online (http://dx.doi.org/10. 1136/bjsports-2013-093272).

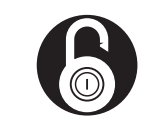

\section{OPEN ACCESS}

Open Access This is an Open Access article distributed in accordance with the Creative Commons Attribution Non Commercial (CC BY-NC 3.0) license, which permits others to distribute, remix, adapt, build upon this work non-commercially, and license their derivative works on different terms, provided the original work is properly cited and the use is non-commercial. See: http:// creativecommons.org/licenses/by-nc/3.0/

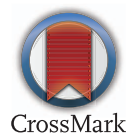

To cite Ellenbecker TS, Stroia KA. Br I Sports Med 2014;48:i5-i6.

Accepted 27 January 2014
Br J Sports Med 2014;48:i5-i6.

doi:10.1136/bjsports-2013-093272

\section{REFERENCES}

1 Reid M, Schneiker K. Strength and conditioning in tennis: current research and practice. J Sc Med Sport 2008;11:248-56.

2 Fernandez J, Mendez-Villanueva A, Pluim B. Intensity of tennis match play. Br J Sports Med 2006;40:387-91.

3 Bergeron MF, Waller J, Marinik E. Voluntary fluid intake and core temperature responses in adolescent tennis players. Br I Sports Med 2006;40:406-10.

4 Bergeron MF, McLeod K, Coyle J. Core body temperature during competition in the heat: National Boys 14's Junior Tennis Championships. Br I Sports Med 2007;41:779-83.

5 Tippet M, Stofan J, Lacambra M, et al. Core temperature and sweat responses in professional women's tennis players during tournament play in the heat. J Athl Train 2011;46:55-60.

6 Hornery D, Farrow D, Mujika L, et al. An integrated physiological and performance profile of professional tennis. Br J Sports Med 2007;41:531-6.

7 Périard J, Racinais S, Knez W, et al. Thermal, physiological and perceptual strain mediate alterations in match-play tennis under heat stress. Br J Sports Med 2014;48:i32-8.

8 Ranalli GF, DeMartini JK, Casa DJ, et al. Effect of body cooling on subsequent aerobic and anaerobic exercise performance. J Strength Cond Res 2010;24:3488-96.

9 Costello JT, Donnelly AE. Effects of cold water immersion on knee joint position sense in healthy volunteers. I Sport Science 2011;29: 449-56.

10 Howatson G, Goodall K, van Someren A. The influence of cold water immersion on adaptation following a single bout of damaging exercise. Eur J Appl Physiol 2009;105:615-21. 